\title{
Functionalization of polyvinyl alcohol composite film wrapped in am-ZnO@CuO@Au nanoparticles for antibacterial application and wound healing
}

Wentao, Wang; Tao, Zheng; Bulei, Sheng; Tongchang, Zhou; Qicheng, Zhang; Fan, Wu; Ninglin, Zhou; Jian, Shen; Zhang, Ming ; Yi, Sun

Published in:

Applied Materials Today

Link to article, DOI:

10.1016/j.apmt.2019.07.001

Publication date:

2019

Document Version

Peer reviewed version

Link back to DTU Orbit

Citation (APA):

Wentao, W., Tao, Z., Bulei, S., Tongchang, Z., Qicheng, Z., Fan, W., Ninglin, Z., Jian, S., Zhang, M., \& Yi, S. (2019). Functionalization of polyvinyl alcohol composite film wrapped in am-ZnO@CuO@Au nanoparticles for antibacterial application and wound healing. Applied Materials Today, 17, 36-44.

https://doi.org/10.1016/j.apmt.2019.07.001

\section{General rights}

Copyright and moral rights for the publications made accessible in the public portal are retained by the authors and/or other copyright owners and it is a condition of accessing publications that users recognise and abide by the legal requirements associated with these rights.

- Users may download and print one copy of any publication from the public portal for the purpose of private study or research.

- You may not further distribute the material or use it for any profit-making activity or commercial gain

- You may freely distribute the URL identifying the publication in the public portal 


\title{
Functionalization of Polyvinyl Alcohol Composite Film Wrapped in
} $a_{m}-Z n O @ C u O @ A u$ Nanoparticles for Antibacterial Application and

\section{Wound Healing}

Wentao Wang ${ }^{\mathrm{a}+}$, Tao Zheng ${ }^{\mathrm{b}+}$, Bulei Sheng ${ }^{\mathrm{c}}$, Tongchang Zhou ${ }^{\mathrm{b}}$, Qicheng Zhang ${ }^{\mathrm{a}}$, Fan Wu $\mathrm{Wu}^{\mathrm{a}}$, Ninglin Zhou ${ }^{\mathrm{a}}$, Jian Shen ${ }^{\mathrm{a}}$, Ming Zhang ${ }^{\mathrm{a}, \mathrm{b}^{*}}$, Yi Sun ${ }^{\mathrm{b}}$

a Jiangsu Collaborative Innovation Center for Biomedical Functional Materials, School of Chemistry and Materials Science, Nanjing Normal University, Nanjing 210023, P. R. China;

${ }^{\mathrm{b}}$ Department of Health Technology, Technical University of Denmark, Kongens Lyngby, 2800, Denmark;

${ }^{c}$ Department of Food Science, Aarhus University, 8830 Tjele, Denmark Corresponding author: Ming Zhang, mzhan@dtu.dk; Yi Sun, suyi@dtu.dk

${ }^{+}$These authors contributed equally to this work.

\begin{abstract}
Over recent years, researchers have been intensively investigating advanced antibacterial agents. However, the drug resistance in bacteria remains to be a challenging problem for wound healing. Therefore, it is urgent to find a novel effective antibacterial therapy to enhance wound healing. Herein, we reported a new antibacterial film (PVA@am-ZnO@CuO@Au) which showed heat, reactive oxygen species (ROS), Zn ${ }^{2+}$, and $\mathrm{Cu}^{2+}$-induced disinfection. An antibacterial efficacy of $98.7 \%$ against E. coli and 97.5\% against $S$. aureus was obtained by PVA@a $a_{m}-\mathrm{ZnO} @ \mathrm{CuO} @ \mathrm{Au}$ film under red laser irradiation for $10 \mathrm{~min}$, with the combined effect of photothermal, photodynamic, and released $\mathrm{Zn}^{2+}$ and $\mathrm{Cu}^{2+}$. In vivo wound healing and tissue compatibility studies were carried out over a period of 10 days on skin wounds. Fast healing was observed in PVA@a $a_{m}-\mathrm{ZnO} @ \mathrm{CuO} @ \mathrm{Au}$ film treated wounds with minimum scarring. PVA@am-ZnO@CuO@Au film also possessed sustained antibacterial properties due to the large embedded depth of $a_{m}-\mathrm{ZnO} @ \mathrm{CuO} @ \mathrm{Au}$ NPs. The technique and resulting
\end{abstract}


materials have large potential for applications in would healing.

Keywords: wound healing; antibacterial; disinfection; photothermal; photodynamic

\section{Introduction}

The variety and rapid variability of pathogenic microorganisms make antibacterial therapy face enormous challenges [1-3]. The problem of drug resistance has been worsened in recent years. For instance, the emergence of "superbugs" resistant to several antibiotics has caused alarm and even panic around the world [4,5]. Therefore, there is an urgent need to develop new effective antibacterial methods. Nanometer antibacterial material is a kind of functional material, which is prepared by making antibacterial agent into nanometer scale or connecting antibacterial agent with nanometer carrier [6-8]. It has been reported that $\mathrm{Zn}^{2+}$ and $\mathrm{Cu}^{2+}$ are widely used as antibacterial agents due to their low toxicity and high biosafety [9-11]. However, disadvantages of discoloration, narrow antibacterial spectrum, poor long-term durability, poor heat resistance and stability have hindered their further development. In contrast, nanomaterials (NMs) such as copper oxide $(\mathrm{CuO})$ and zinc oxide $(\mathrm{ZnO})$ nanoparticles $(\mathrm{NPs})$ can overcome these problems to some extent [12-13]. Recently, with the development of nanotechnology, a series of low-dimensional structure $\mathrm{CuO} @ \mathrm{ZnO}$ hybrid NMs has emerged, which provided great space for the development of $\mathrm{CuO}$ and $\mathrm{ZnO}$-based antibacterial materials with lower toxicity and longer effective time $[14,15]$. Thus, it has been the hotspot to improve the antibacterial activity of NMs by the synergistic effect generated via coupling hybrid nanomaterials.

Antimicrobial phototherapies, such as photothermal and photodynamic, have broad-spectrum antibacterial properties and show great potential for the treatment of bacterial infections $[16,17]$. Based on nanotechnology, the form of nano-antibacterial technology by NMs with photothermal conversion and photodynamic effects have drawn increasing attention [18]. Upon the excitation by light source at specific wavelength, heat 
and reactive oxygen species (ROS) are generated, which can kill the bacteria as a result of protein denaturation, enzyme inactivity and imbalance of metabolic activity [19]. The damage mechanism of ROS to bacteria can be mainly concluded into two pathways: (1) destroying the plasma membrane permeability to make some substances flow out, or affecting the metabolic activities of the bacteria; (2) breaking and disaggregating DNA strands, generating stable oxidation products [20-22]. Photo antibacterial technology has high level of sterilization, good safety and lower risk in causing the emergence of drug-resistant bacteria $[23,24]$. Therefore, it is a new therapy with broad application prospects, and this technology will make a breakthrough with the emergence of new photothermal agents and photosensitizers.

It is necessary for wound healing to minimize infections at wound sites $[25,26]$. Furthermore, it is quite important to choose NMs with good biocompatibility to participate in antibacterial activity to accelerate wound healing, Wound healing is a complex, dynamic, and sequential process associated with coagulation, inflammation, angiogenesis, tissue formation, and tissue remodeling. Various photothermal agents such as Au nanoparticles (AuNPs), transition metal sulfides, carbon nanotubes (CNTs), and graphene oxide (GO) have been reported [27-30]. Among them, AuNPs are preferred due to their high absorption ability in the red light region and excellent biocompatibility. Meanwhile, a strong photothermal conversion capability can be achieved through adjusting their morphology and size to make the plasmon resonance absorption peak move to the red light region, thereby increasing the local temperature and killing bacteria [31,32]. $\mathrm{CuO}$ and $\mathrm{ZnO}$ NPs have been considered as powerful photosensitizers among various semiconductor materials [33,34]. However, the application of $\mathrm{CuO}$ and $\mathrm{ZnO} \mathrm{NPs}$ as photocatalysts is hampered by two constraints: limited light utilization conferred by a wide band gap, and low quantum efficiency due to the recombination of photo-generated electrons and holes. Coupling $\mathrm{CuO}$ or $\mathrm{ZnO}$ NPs with AuNPs has been envisioned as an effective strategy to overcome these barriers. Hence, an approach to obtain uniform 
$\mathrm{CuO} @ \mathrm{ZnO}$ hybrid NMs with AuNPs in each $\mathrm{CuO} @ \mathrm{ZnO}$ hybrid NMs by the in situ reduction process is needed.

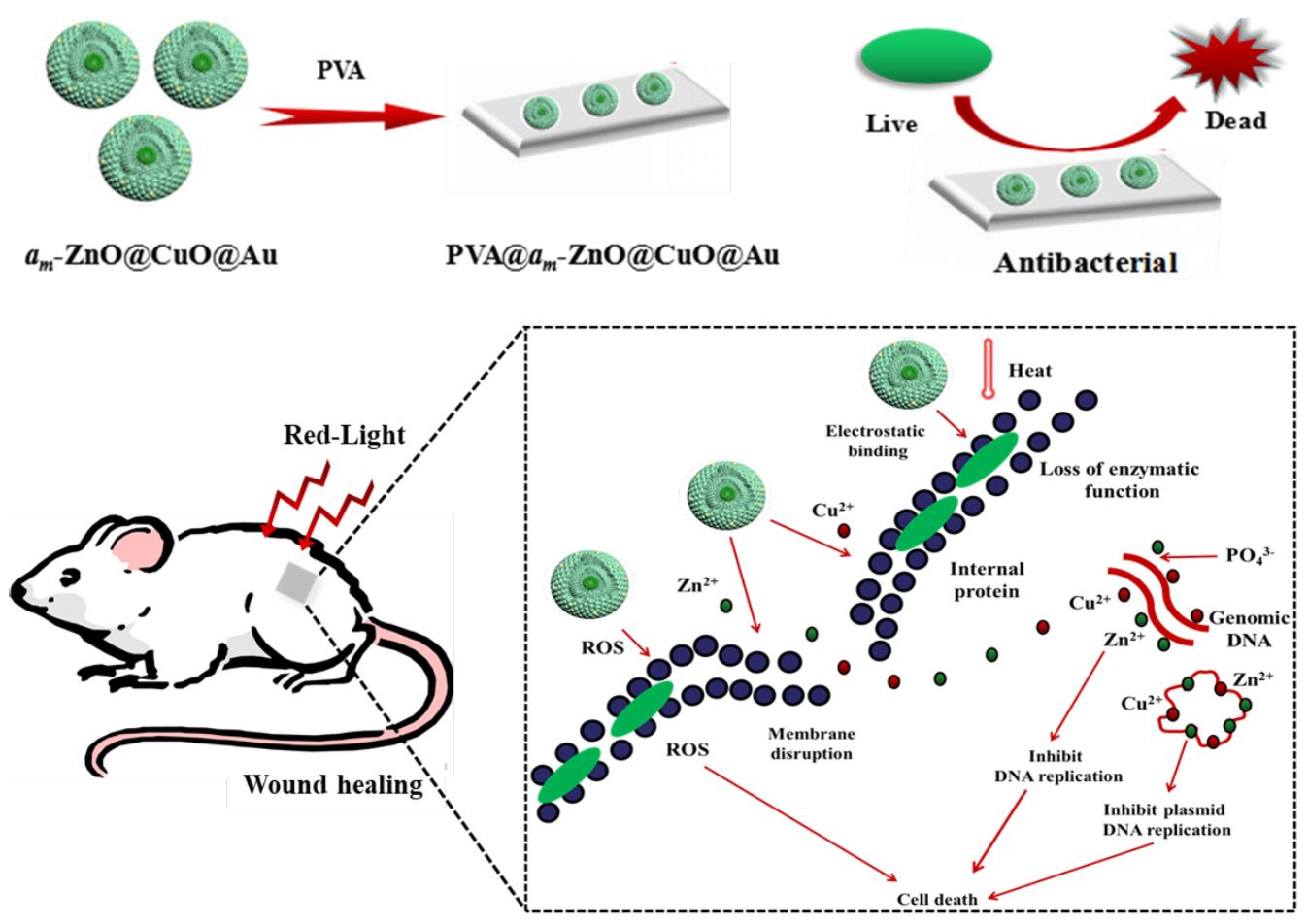

Fig. 1. Schematic illustration of PVA antibacterial film embedded with $a_{m}-\mathrm{ZnO} @ \mathrm{CuO} @ \mathrm{Au} \mathrm{NPs}$ for antibacterial wound dressings.

Taking the above development and their limitations into consideration, we utilized a reported strategy to prepare a hybrid multi-shelled hollow materials with binary compositions of $\mathrm{ZnO} @ \mathrm{CuO} @ \mathrm{Au} \mathrm{NPs}$, based on copper-aided oxidative degradation of an amorphous $\left(a_{m}\right)$ zeolitic imidazolate frameworks (ZIFs). Subsequently, the $a_{m}-\mathrm{ZnO} @ \mathrm{CuO} @ \mathrm{Au}$ NPs were embedded in polyvinyl alcohol (PVA) film (PVA@a $\left.a_{m}-\mathrm{ZnO} @ \mathrm{CuO} @ \mathrm{Au}\right)$ to achieve great antibacterial activity. In contrast to cancer therapy, simultaneous antibacterial therapy has seldom been reported. By taking advantage of the photothermal and photodynamic effects of $a_{m}-\mathrm{ZnO} @ \mathrm{CuO} @ \mathrm{Au} \mathrm{NPs}$, angiogenesis of $\mathrm{Zn}^{2+}$ and $\mathrm{Cu}^{2+}$, and moist conditions, the materials offered antibacterial activity and tissue regeneration capability at the same time (as shown in Fig. 1). The different antibacterial characteristics of PVA@a $a_{m}-\mathrm{ZnO} @ \mathrm{CuO} @ \mathrm{Au}$ film and subsequent 
biocompatibility were systematically assessed both in vitro and in vivo.

\section{Results and discussion}

\subsection{Fabrication and characterization of the $a_{m}-\mathrm{ZnO} @ \mathrm{CuO@AuNPs}$}

A hybrid multi-shelled nanoparticles $\left(a_{m}-\mathrm{ZnO} @ \mathrm{CuO} @ \mathrm{Au}\right.$ NPs $)$, based on copper-aided oxidative degradation of an amorphous zeolitic imidazolate frameworks ( $a_{m}$-ZIFs), is illustrated in Fig. S1. Firstly, $a_{m}$-ZIFs in rhombic dodecahedral form was synthesized by directly mixing zinc nitrate aqueous solution with ICA methanolic solution at room temperature for $45 \mathrm{~min}$. Next, CuNPs with an average size of $3.1 \pm 0.4$ $\mathrm{nm}$ and AuNPs with an average size of $2.9 \pm 0.6 \mathrm{~nm}$ were introduced to $a_{m}$-ZIF (am-ZIF@Cu@Au NPs) through an in situ reduction method by using $\mathrm{Cu}(\mathrm{acac})_{2}$ as a $\mathrm{Cu}$ source, $\mathrm{HAuCl}_{4}$ as a $\mathrm{Au}$ source and tetrabutylammonium borohydride $\left(\mathrm{R}-\mathrm{NBH}_{4}\right)$ as a reducing agent. Finally, the obtained $a_{m}-\mathrm{ZIF} @ \mathrm{CuO} @ \mathrm{Au}$ NPs was calcined in $280{ }^{\circ} \mathrm{C}$ tube furnace to form $a_{m}-\mathrm{ZnO} @ \mathrm{CuO} @ \mathrm{Au}$ NPs. TEM was employed to investigate the shape features, surface morphology and size determination of the as-synthesized $a_{m}$-ZIF NPs, $a_{m}$-ZIF@Cu@Au NPs, and $a_{m}$-ZnO@CuO@Au NPs. As shown in Fig. 2A, $a_{m}$-ZIF NPs have a unique sphere structure with the average size of $550 \mathrm{~nm}$. By the in situ synthesis of $a_{m}$-ZIF@Cu@Au NPs, the NPs was covered with AuNPs of varying sizes (Fig. 2B). As shown in the TEM images (Fig. 2C,a,b), by calcining $a_{m}$-ZIF@Cu@Au NPs at $280{ }^{\circ} \mathrm{C}$, well-defined multi-shelled hollow NPs with an average hydrodynamic diameter around $425 \mathrm{~nm}$ were produced. Fig. 2C,c,d shows a HR-STEM image of $a_{m}-\mathrm{ZnO} @ \mathrm{CuO} @ \mathrm{Au} \mathrm{NPs}$, and the corresponding Au, Zn, and $\mathrm{Cu}$ element maps are shown in Fig. 2D, respectively. The corresponding EDX spectrum (Fig. S2A) shows characteristic energy lines of $\mathrm{Cu}, \mathrm{Zn}, \mathrm{Au}$, and $\mathrm{O}$ arising from the $\mathrm{CuO}, \mathrm{ZnO}$, and AuNRs. Additionally, the XRD pattern (Fig. S2B) further supports the formation of $a_{m}-\mathrm{ZnO} @ \mathrm{CuO} @ \mathrm{Au}$ hybrid structures. 

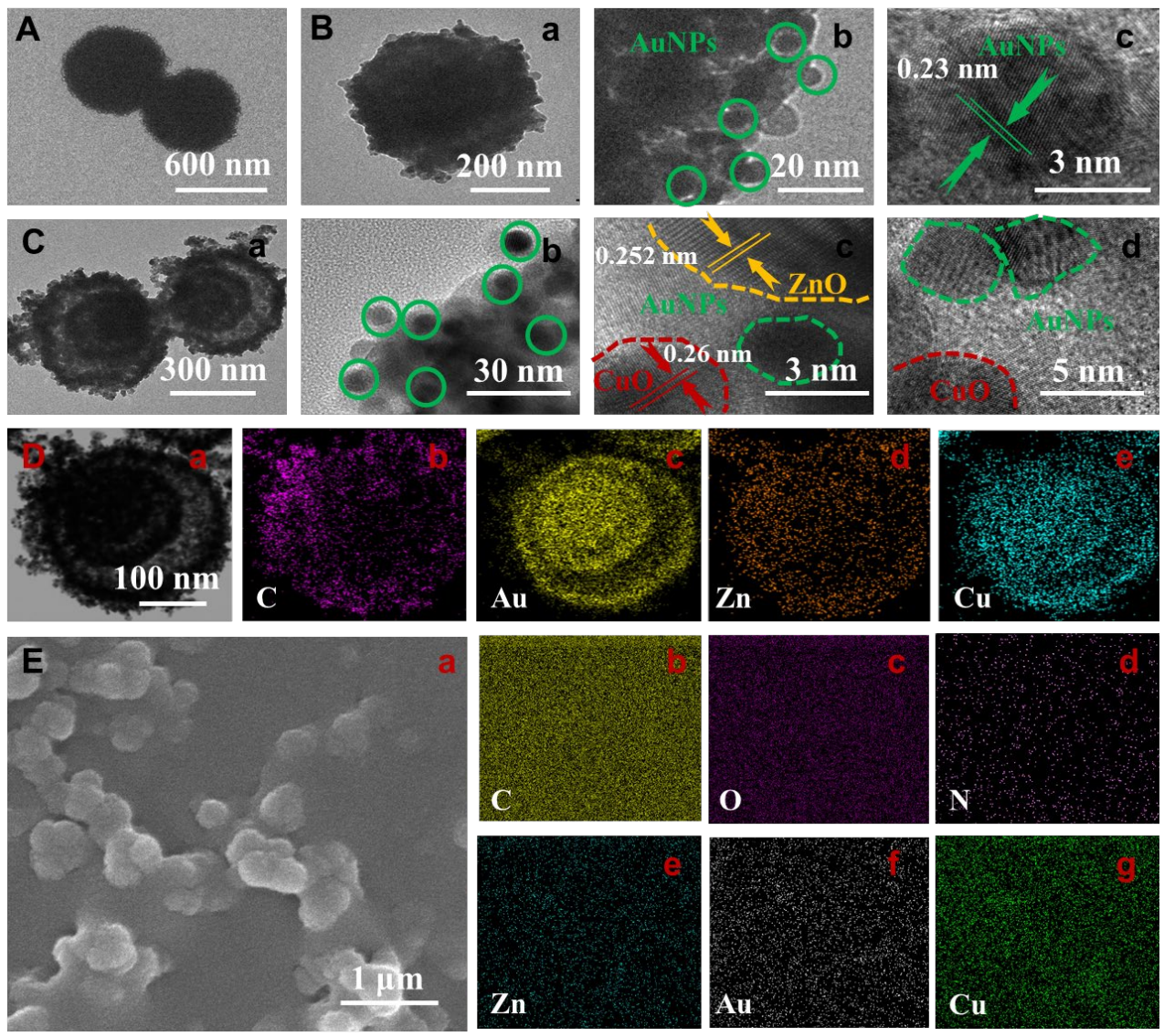

Fig. 2. (A) TEM images of $a_{m}$-ZIF NPs. (B) TEM images $(a, b)$ and HR-TEM (c) of $a_{m}$-ZIF@Cu@Au NPs. (C) TEM images $(\mathrm{a}, \mathrm{b})$ and HR-TEM (c,d) of $a_{m}-\mathrm{ZnO} @ \mathrm{CuO} @ \mathrm{Au}$ NPs. The lattice spacing of $0.23 \mathrm{~nm}$ is attributed to the facet of Au. (D) TEM images (a) of $a_{m}-\mathrm{ZnO} @ \mathrm{CuO} @ \mathrm{Au}$ NPs and their corresponding EDS elemental mapping images (b-e). The lattice fringes can be resolved, which are attributed to $\mathrm{ZnO}$ and $\mathrm{CuO}$, respectively. (E) The SEM images (a) of $a_{m}-\mathrm{ZnO} @ \mathrm{CuO} @ \mathrm{Au}$ NPs and their corresponding EDS elemental mapping images $(b-g)$.

2.2 Fabrication and characterization of the PVA@a $a_{m}-\mathrm{ZnO} @ \mathrm{CuO@AuNPs}$ film

After radical polymerization, the functional $a_{m}-\mathrm{ZnO} @ \mathrm{CuO} @ \mathrm{Au}$ NPs were embedded in a PVA film. As shown in Fig. S3, the surface of the pure PVA film was flat. After the incorporation of functional $a_{m}-\mathrm{ZnO} @ \mathrm{CuO} @ \mathrm{Au} \mathrm{NPs}$, many NPs were found to be incorporated into the PVA film and their uniform distribution was confirmed by EDS 
elemental mapping (Fig. 2). The corresponding EDX spectrum (Fig. S4) shows characteristic energy lines of $\mathrm{Cu}, \mathrm{Zn}, \mathrm{Au}$, and $\mathrm{N}$ arising from the $a_{m}-\mathrm{ZnO} @ \mathrm{CuO} @ \mathrm{Au}$ NPs. The PVA@a $a_{m}-\mathrm{ZnO} @ \mathrm{CuO} @ \mathrm{Au}$ film showed diffraction peaks matching the free $a_{m}-\mathrm{ZnO} @ \mathrm{CuO} @ \mathrm{Au} \mathrm{NPs}$ structure, further proving successful loading of $a_{m}-\mathrm{ZnO} @ \mathrm{CuO} @ \mathrm{Au}$ NPs into the PVA film. Furthermore, we compared the mechanical properties of pure PVA and composite PVA film containing different amount of $a_{m}-\mathrm{ZnO} @ \mathrm{CuO} @ \mathrm{Au}$ NPs (PVA@a $a_{m}-\mathrm{ZnO} @ \mathrm{CuO} @ \mathrm{Au}$ 1-3) with a thickness about $0.1 \mathrm{~cm}$.

As shown in Table S1, PVA@a $a_{m}-\mathrm{ZnO} @ \mathrm{CuO} @ \mathrm{Au}$ film exhibited higher tensile strength than pure PVA. Similarly, there was an increase of $25 \%$ of the Young's modulus of the PVA-based film due to the incorporation of $a_{m}-\mathrm{ZnO} @ \mathrm{CuO} @ \mathrm{Au}$ NPs.

\subsection{Photodynamic performance of the PVA@a $a_{m}-\mathrm{ZnO} @ C u O @ A u$ film}

ESR spin trapping and spin labeling are two recognized techniques for the detection of short-lived free radicals and paramagnetic species [35,36]. Here, we select 5-tertbutoxycarbonyl-5-methyl-1-pyrroline N-oxide (BMPO) as a spin trap for the hydroxyl radical $(\cdot \mathrm{OH}), 4$-oxo-2,2,6,6-tetramethylpiperidine (4-oxo-TEMP) for detection of singlet oxygen $\left({ }^{1} \mathrm{O}_{2}\right)$. Fig. 3A and Fig. S5 shows the ESR spectra obtained from solutions containing various spin probes and $a_{m}-\mathrm{ZnO} \mathrm{NPs}, a_{m}-\mathrm{ZnO} @ \mathrm{CuO} \mathrm{NPs}$, $a_{m}-\mathrm{ZnO} @ \mathrm{Au} \mathrm{NPs}, a_{m}-\mathrm{ZnO} @ \mathrm{CuO} @ \mathrm{Au} \mathrm{NPs}$, and PVA@a $a_{m}-\mathrm{ZnO} @ \mathrm{CuO} @ \mathrm{Au} 3$ film during irradiation with simulated red laser. No ESR signal was observed for spin probes $a_{m}-\mathrm{ZnO}$ NPs. In contrast, upon irradiation for $10 \mathrm{~min}$ in the presence of $a_{m}-\mathrm{ZnO} @ \mathrm{Au}$ NPs, $a_{m}-\mathrm{ZnO} @ \mathrm{CuO} @ \mathrm{Au}$ NPs, and PVA@a $a_{m}-\mathrm{ZnO} @ \mathrm{CuO} @ \mathrm{Au}$ film, we clearly observed a four-line spectrum and there-line spectrum which was the characteristic spectrum for the $\mathrm{BMPO} / \cdot \mathrm{OH}$ and 4-oxo-TEMP $/{ }^{1} \mathrm{O}_{2}$ adduct, respectively. Compared to the EPR signal intensity of $a_{m}-\mathrm{ZnO} \mathrm{NPs}, a_{m}-\mathrm{ZnO} @ \mathrm{CuO} \mathrm{NPs}$, and $a_{m}-\mathrm{ZnO} @ \mathrm{Au} \mathrm{NPs}$, the BMPO/·OH and 4-oxo-TEMP $/{ }^{1} \mathrm{O}_{2}$ signal intensity of $a_{m}-\mathrm{ZnO} @ \mathrm{CuO} @ \mathrm{Au}$ NPs increased significantly, suggesting that deposition of AuNPs onto $\mathrm{ZnO}$ and $\mathrm{CuO}$ significantly enhanced 
photogeneration of $\cdot \mathrm{OH}$ and ${ }^{1} \mathrm{O}_{2}$. Interestingly, when $a_{m}-\mathrm{ZnO} @ \mathrm{CuO} @ \mathrm{Au}$ NPs were embedded into PVA film, the $\mathrm{BMPO} / \cdot \mathrm{OH}$ and 4 -oxo-TEMP $/{ }^{1} \mathrm{O}_{2}$ signal intensity of PVA@a $a_{m}-\mathrm{ZnO} @ \mathrm{CuO} @ \mathrm{Au} 3$ film was similar to $a_{m}-\mathrm{ZnO} @ \mathrm{Au}$ NPs.

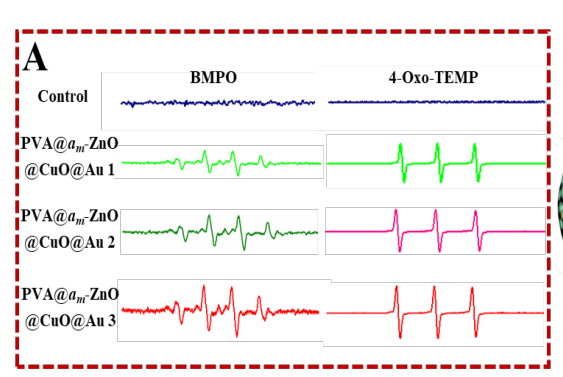

B
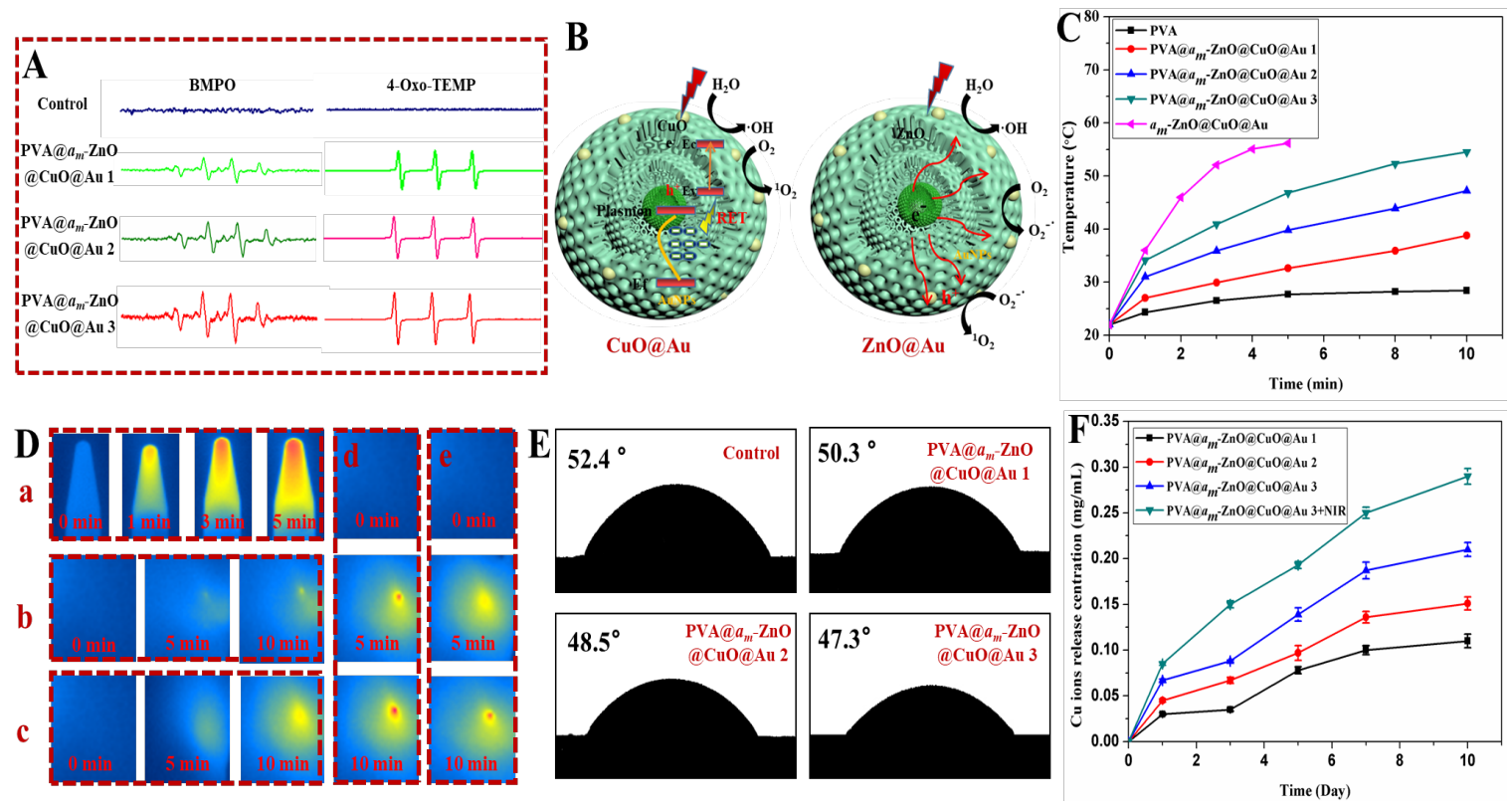

Fig. 3. (A) ESR spectra obtained from solutions containing BMPO/4-Oxo-TEMP and PVA@a $a_{m}-\mathrm{ZnO} @ \mathrm{CuO} @ \mathrm{Au}$ film after irradiated with red laser irradiation. (B) The expected reaction mechanism for the enhancement effect on generating ROS. (C) The irradiation time-dependent temperature elevation of different samples. (D) IR images of different samples (a, $a_{m}-\mathrm{ZnO} @ \mathrm{CuO} @ \mathrm{Au}$ NPs solution; b, pure PVA film; c-e, PVA@a $a_{m} \mathrm{ZnO} @ \mathrm{CuO} @ \mathrm{Au}$ 1-3 film) under red laser irradiation. (E) Water contact angles of pure PVA film and PVA@a $a_{m}-\mathrm{ZnO} @ \mathrm{CuO} @ \mathrm{Au}$ film. (F) Cumulative amounts of $\mathrm{Cu}^{2+}$ released from PVA@a $a_{m}-\mathrm{ZnO} @ \mathrm{CuO} @ \mathrm{Au}$ film with and without red laser irradiation.

The mechanism of ROS generation induced by the photodynamic $a_{m}-\mathrm{ZnO} @ \mathrm{CuO} @ \mathrm{Au}$ NPs is schematically displayed in Fig. 3B. For $a_{m}-\mathrm{ZnO} @ \mathrm{CuO} @ \mathrm{Au} \mathrm{NPs}$, the observed enhanced ROS generation may result from the following effects of AuNPs: (1) enhancing light absorption because of the SPR of $\mathrm{Au}$; (2) changing the band gap of $\mathrm{ZnO} / \mathrm{CuO}$ and thereby promoting reactivity of photoinduced charge carriers, and (3) increasing the efficiency of electron transport and charge carrier separation [37,38]. This indicated that increased absorption of light through the SPR of AuNPs did play a role in the enhanced photoactivity observed for the $a_{m}-\mathrm{ZnO} @ \mathrm{Au}$ and $a_{m}-\mathrm{ZnO} @ \mathrm{CuO} @ \mathrm{Au}$ HNSs. The 
photo-induced electrons transfer from AuNPs to $\mathrm{ZnO} / \mathrm{CuO}$ conduction band after exposure to red laser irradiation. The transfered electrons in the conduction band and the holes in the valence band continuously induce a series of photochemical reactions to generate $\mathrm{ROS}$ at $a_{m}-\mathrm{ZnO}$ or $\mathrm{CuO}$ surfaces in the aqueous solution. On the contrary, on the surface of pristine AuNPs, red laser irradiation produced photoelectrons and Auger electrons, which subsequently participated in ROS-generating reactions. However, $a_{m}-\mathrm{ZnO} @ \mathrm{CuO}$ and $a_{m}-\mathrm{ZnO}$ did not play exclusively separate roles in ROS generation during photochemical reactions, and the simple stacking of each effect from $\mathrm{Au}$ and $a_{m}-\mathrm{ZnO} @ \mathrm{CuO}$ was insufficient to explain the great enhancement in the observed ROS yield.

\subsection{Photothermal performance of thePVA@a $a_{m}-Z n O @ C u O @ A u N P s$ film}

The absorption spectra of $a_{m}-\mathrm{ZnO} @ \mathrm{CuO} @ \mathrm{Au}$ NPs and PVA@a $a_{m}-\mathrm{ZnO} @ \mathrm{CuO} @ \mathrm{Au}$ film showed a strong broad red light absorption (Fig. S6). We initially investigated the temperature changes of am-ZnO@CuO@Au and PVA@am-ZnO@CuO@Au film under $2.0 \mathrm{~W} / \mathrm{cm}^{2}$ of $635 \mathrm{~nm}$ laser irradiation. The temperature of $a_{m}-\mathrm{ZnO} @ \mathrm{CuO} @ \mathrm{Au} \mathrm{NPs}$ increased to $56.4{ }^{\circ} \mathrm{C}$ after 5 min of irradiation, confirming the fast and high-efficient photothermal conversion capacity of am-ZnO@CuO@Au NPs. The temperature of the PVA@a $a_{m}-\mathrm{ZnO} @ \mathrm{CuO} @ \mathrm{Au}$ film could be accurately regulated to increase from $13.5{ }^{\circ} \mathrm{C}$ (PVA@a $\left.a_{m}-\mathrm{ZnO} @ \mathrm{CuO} @ \mathrm{Au} 1\right)$ to $27.2{ }^{\circ} \mathrm{C} \quad\left(\mathrm{PVA} @ a_{m}-\mathrm{ZnO} @ \mathrm{CuO} @ \mathrm{Au}\right.$ 3) under irradiation for $10 \mathrm{~min}$, while pure PVA film increases only increased by $3.2{ }^{\circ} \mathrm{C}$ (Fig. 3C). A thermal imaging camera was used to record the temperature variation and the results further confirmed the successful converting red light to heat (Fig. 3D).

Wound dressings should be mechanically robust and hydrophilic to obtain fine permeability, which was beneficial for wound healing [39]. Therefore, we measure the tensile strength and contact angle of pure PVA film and PVA@a $a_{m}-\mathrm{ZnO} @ \mathrm{CuO} @ \mathrm{Au}$ film. When we placed the water on the fibers, the water contact angle was $52.4^{\circ}$ (wettability) 
(Fig. 3E). Contact angle measurement revealed that the addition of $a_{m}-\mathrm{ZnO} @ \mathrm{CuO} @ \mathrm{Au}$ to PVA film (PVA@a $a_{m}-\mathrm{ZnO} @ \mathrm{CuO} @ \mathrm{Au}$ 1. PVA@a $a_{m}-\mathrm{ZnO} @ \mathrm{CuO} @ \mathrm{Au}$ 2, and PVA@a $\left.a_{m}-\mathrm{ZnO} @ \mathrm{CuO} @ \mathrm{Au} 3\right)$ retained the hydrophilicity of PVA film. The results of water absorption experiments for PVA film and PVA@a $a_{m}-\mathrm{ZnO} @ \mathrm{CuO} @ \mathrm{Au}$ film are shown in Table S2. With the increase of $a_{m}-\mathrm{ZnO} @ \mathrm{CuO} @ \mathrm{Au}$ NPs content, the water absorption of PVA@am-ZnO@CuO@Au film was increased compared with pure PVA film. This was because the addition of functionalized $a_{m}-\mathrm{ZnO} @ \mathrm{CuO} @ \mathrm{Au}$ NPs contributed to the slightly increase of cross-linking density of PVA composite.

\section{$2.5 \mathrm{Zn}^{2+}$ and $\mathrm{Cu}^{2+}$ Releasing from the PVA@a $a_{m}-\mathrm{ZnO@CuO@Aufilm}$}

Fig. 3F and Fig. S7 exhibits the cumulative concentrations of $\mathrm{Cu}$ and $\mathrm{Zn}$ ions released from the different film (PVA@a $a_{m}-\mathrm{ZnO} @ \mathrm{CuO} @ \mathrm{Au}$ 1-3) to the PBS (pH 7.4) at $37{ }^{\circ} \mathrm{C}$. The PVA@am-ZnO@CuO@Au 1-3 film showed a similar release behavior with slow release of $\mathrm{Cu}^{2+}$ and $\mathrm{Zn}^{2+}$. PVA $/ a_{m}-\mathrm{ZnO} @ \mathrm{CuO} @ \mathrm{Au} 3$ showed the biggest release while PVA@am-ZnO@CuO@Au 1 was the smallest, consistent with the embedded $a_{m}-\mathrm{ZnO} @ \mathrm{CuO} @ \mathrm{Au} \mathrm{NPs}$ contents. The $\mathrm{Zn}^{2+}$ and $\mathrm{Cu}^{2+}$ were formed by the dissociation of ions from the $a_{m}-\mathrm{ZnO} @ \mathrm{CuO} @ \mathrm{Au}$ NPs. To explore the effects of laser on the release of $\mathrm{Zn}^{2+}$ and $\mathrm{Cu}^{2+}$, PVA@a $a_{m}-\mathrm{ZnO} @ \mathrm{CuO} @ \mathrm{Au} 3$ was monitored with or without $635 \mathrm{~nm}$ laser. As shown in Fig. 3F and Fig. S7, the release of $\mathrm{Zn}^{2+}$ and $\mathrm{Cu}^{2+}$ under laser illumination were enhanced. The enhanced release of $\mathrm{Zn}^{2+}$ and $\mathrm{Cu}^{2+}$ under laser illumination was probably because of the photothermal conversion function of PVA@a $a_{m}-\mathrm{ZnO} @ \mathrm{CuO} @ \mathrm{Au}$ film, which may occur during the volume shrinkage process owing to the burst release of soluble materials in film carrier.

\subsection{In intro antibacterial assessment of PVA@ $a_{m}-Z n O @ C u O @ A u f i l m$}

For wound healing, the antibacterial properties of biomaterials are a major standard for defining an eligible wound dressing [40]. To assess this ability, the antibacterial efficacy 
of PVA@am-ZnO@CuO@Au film against E. coli (Fig.4A) and S. aureus (Fig. 4B)was measured with or without $635 \mathrm{~nm}$ laser irradiation. Consequently, the PVA@a $a_{m}-\mathrm{ZnO} @ \mathrm{CuO} @ \mathrm{Au}$ film exhibited low antibacterial properties in the dark against both bacteria, which was enhanced with increasing $a_{m}-\mathrm{ZnO} @ \mathrm{CuO} @ \mathrm{Au} \mathrm{NPs}$ content. However, the antibacterial properties were improved enormously, and the PVA@am-ZnO@CuO@Au film possessed excellent antibacterial abilities under laser irradiation, In addition, as shown in Fig. 4C,D, the antibacterial ability of the PVA@a $a_{m}-\mathrm{ZnO} @ \mathrm{CuO} @ \mathrm{Au}$ film increased with the increasing $a_{m}-\mathrm{ZnO} @ \mathrm{CuO} @ \mathrm{Au} \mathrm{NPs}$ content under $635 \mathrm{~nm}$ laser irradiation, when the antibacterial rate even reached $98 \%$, while the dark group only reached $53 \%$. This discrepancy may be related to release $\mathrm{Zn}^{2+} / \mathrm{Cu}^{2+}$ to damage bacterial cell membranes, causing the cytoplasm to leak, resulting in antibacterial properties. However, $635 \mathrm{~nm}$ laser irradiation can induce $a_{m}-\mathrm{ZnO} @ \mathrm{CuO} @ \mathrm{Au}$ NPs to generate heat and abundant ROS, and accelerate $\mathrm{Zn}^{2+} / \mathrm{Cu}^{2+}$ release, resulting in a boost in antibacterial efficacy (Fig. 1). We next confirmed the photodynamic therapy efficacy of PVA@a $a_{m}-\mathrm{ZnO} @ \mathrm{CuO} @ \mathrm{Au}$ film at low laser power doses. A significant enhancement in antibacterial efficacy was observed when the PVA@a $a_{m}-\mathrm{ZnO} @ \mathrm{CuO} @ \mathrm{Au}$ film was illuminated by red laser $\left(0.1 \mathrm{~W} / \mathrm{cm}^{2}\right)$ for only 10 min, which was predominantly ascribed to the rapid production of intensive ROS from PVA@am-ZnO@CuO@Au NPs after irradiation (Fig. S8A,B).

To understand the antibacterial mechanism, the interaction of PVA@am-ZnO@CuO@Au film with S. aureus and E. coli bacteria were studied under $635 \mathrm{~nm}$ laser irradiation by SEM. Extensive membrane damage was observed in E. coli and $S$. aureus treated with PVA@am-ZnO@CuO@Au film with 635 nm laser irradiation (Fig. 4E). In comparison, with pure PVA film, the typical morphology of $S$. aureus and $E$. coli with a smooth surface and spherical and rod shape were observed, respectively. The damaged morphology and cell rupture could be attributed to the binding and internalization of PVA@a $a_{m}-\mathrm{ZnO} @ \mathrm{CuO} @ \mathrm{Au}$ film. To further verify its antibacterial 
efficacy, Cy5.5/FITC staining was used to observe the adhesion of bacteria. As shown in Fig. 4F, the results indicated that as the $a_{m}-\mathrm{ZnO} @ \mathrm{CuO} @ \mathrm{Au}$ concentration increased, the number of adherent bacteria decreased (red is E. coli and greed is $S$. aureus), which was consistent with the above results. Taken together, TEM and bacterial fluorescence images were clear evidence for the antibacterial effects of PVA@a $a_{m}-\mathrm{ZnO} @ \mathrm{CuO} @ \mathrm{Au}$ film under $635 \mathrm{~nm}$ laser irradiation.

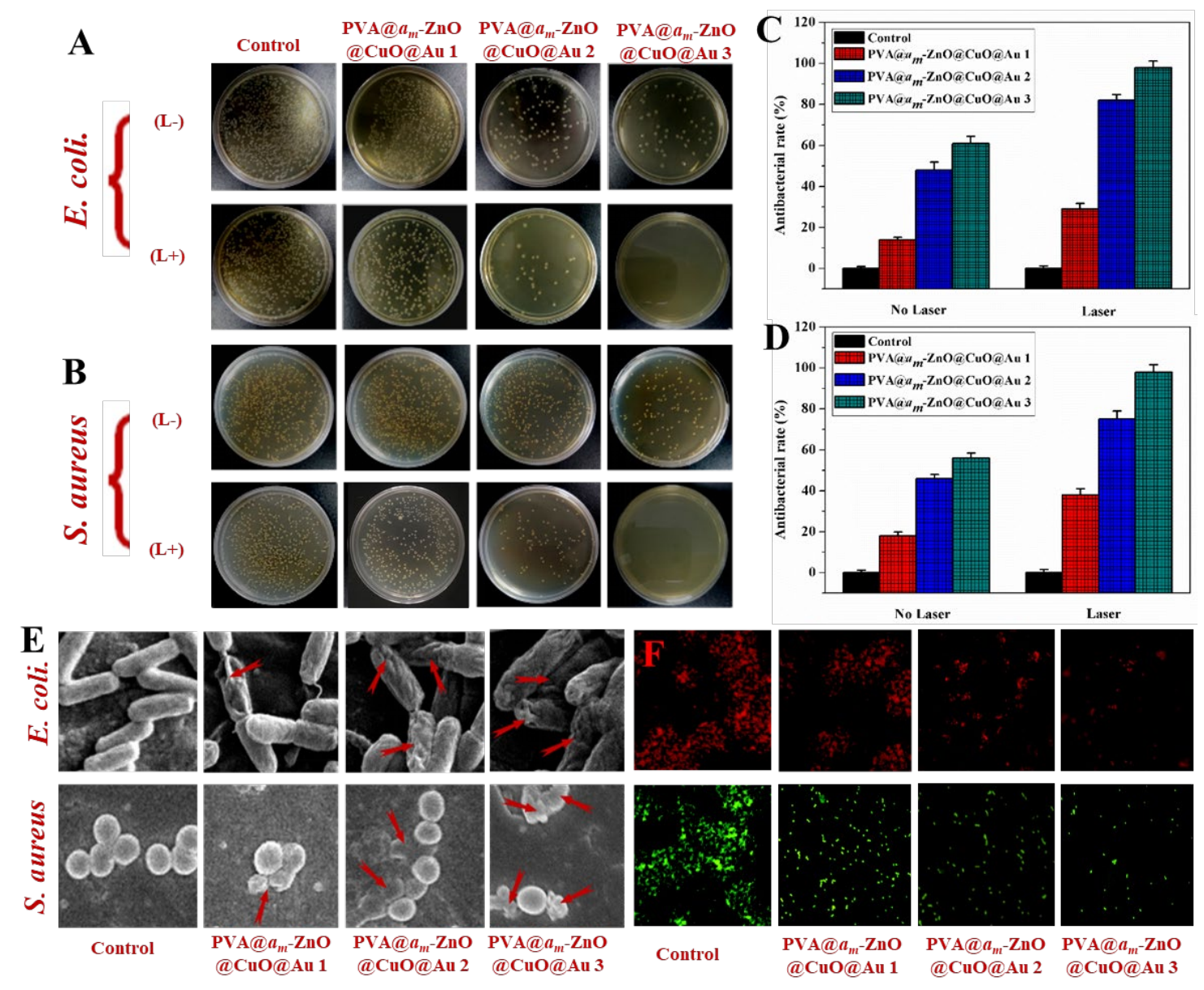

Fig. 4. Antibacterial efficacy $(\mathrm{A}, \mathrm{B})$ and antibacterial rate $(\mathrm{C}, \mathrm{D})$ of $\mathrm{PVA} @ a_{m}-\mathrm{ZnO} @ \mathrm{CuO} @ \mathrm{Au}$ film against $E$. coli $(\mathrm{A}, \mathrm{C})$ and $S$. aureus $(\mathrm{B}, \mathrm{D})$ without and with red laser $\left(2.0 \mathrm{~W} / \mathrm{cm}^{2}\right)$ irradiation. (E) SEM micrographs of $E$. coli and $S$. aureus treated with PVA@a $a_{m}-\mathrm{ZnO} @ \mathrm{CuO} @ \mathrm{Au}$ film after laser irradiation for $10 \mathrm{~min}$. (F) The adhered E. coli and $S$. aureus with laser irradiation were stained by Cy 5.5 and FITC.

\subsection{In intro cytotoxicity assessment of PVA@am-ZnO@CuO@Au film}


The cytotoxicity of PVA@a $a_{m}-\mathrm{ZnO} @ \mathrm{CuO} @ \mathrm{Au}$ film was evaluated with or without 635 $\mathrm{nm}$ laser irradiation [41]. Fig. 5A shows low-level biological toxicity of PVA@a $a_{m}-\mathrm{ZnO} @ \mathrm{CuO} @ \mathrm{Au}$ film through culturing with NIH-3T3 fibroblast cells, even at relatively high concentrations (PVA@a $\left.a_{m}-\mathrm{ZnO} @ \mathrm{CuO} @ \mathrm{Au} 3\right)$. The cells were then stained with both propidium iodide (PI) and calcein AM to identify dead and live cells, respectively (Fig. 5B). The full screen green fluorescence in the region without $635 \mathrm{~nm}$ laser treatment, illustrated that PVA@a $a_{m}-\mathrm{ZnO} @ \mathrm{CuO} @ \mathrm{Au}$ film did not cause cancer cell death without $635 \mathrm{~nm}$ laser irradiation. After $635 \mathrm{~nm}$ laser irradiation, a slightly inhibition ratios against NIH-3T3 cells occurred (Fig. S9), because of heat and ROS produced from the $a_{m}-\mathrm{ZnO} @ \mathrm{CuO} @ \mathrm{Au} \mathrm{NPs}$ by $635 \mathrm{~nm}$ laser irradiation. It showed that short periods of laser could affect the cell growth, but not completely. In in vivo animal experiments, the NIH-3T3 cells proliferation of PVA@am-ZnO@CuO@Au film was evaluated, as shown in Fig.S10. PVA@a $a_{m}-\mathrm{ZnO} @ \mathrm{CuO} @ \mathrm{Au}$ film was suitable for growth, attaining a significant level of increase in cell proliferation after 5 and 7 days of culture.

Platelet aggregation and adhesion are important ways to induce activating blood coagulation process, as well main examination indexes [42]. Platelet adhesion experiments utilized the ability of platelets to aggregate and adhere. SEM was used to observe the adhesion of platelets on the surface of the materials, and study its ability in enriching platelets. As shown in Fig. 5C, the number of adherent platelets of PVA@a $a_{m}-\mathrm{ZnO} @ \mathrm{CuO} @ \mathrm{Au}$ film were significantly increased compared with pure PVA film. This result could be attributed to the strong electrostatic interaction of PVA@a $a_{m}-\mathrm{ZnO} @ \mathrm{CuO} @ \mathrm{Au}$ film surface with platelets, which would affect platelet adhesion and activation, and activate platelets. Therefore, platelets on the surface of the PVA@a $a_{m}-\mathrm{ZnO} @ \mathrm{CuO} @ \mathrm{Au}$ film can activate adjacent platelets to aggregate on the surface of the film, causing a series of blood coagulation reactions, thereby promoting blood coagulation and accelerating wound healing. 

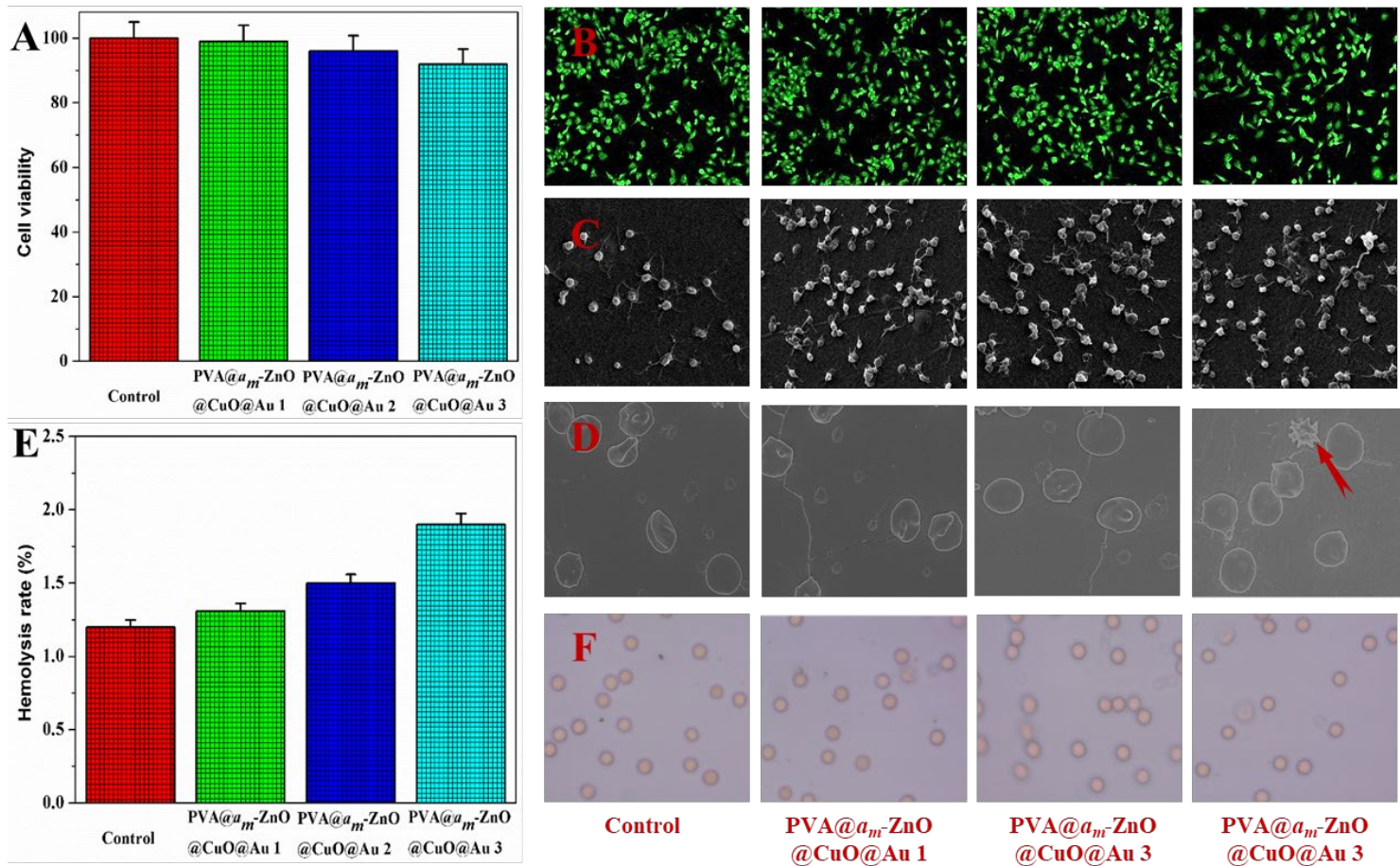

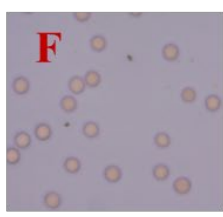

Control

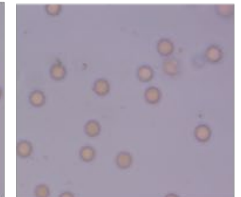

PVA@ $a_{m}-\mathrm{ZnO}$ @CuO@Au 1

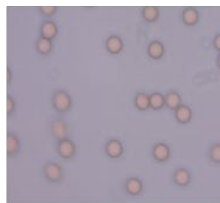

PVA@ $a_{m}-\mathrm{ZnO}$ @CuO@Au3
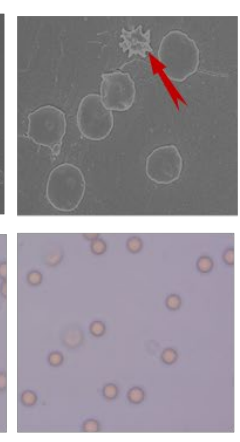

PVA@a $a_{m}$ ZnO @CuO@Au 3

Fig. 5. (A) Cell viability of NIH-3T3 cells incubated with PVA@a $a_{m}-\mathrm{ZnO} @ \mathrm{CuO} @ \mathrm{Au}$ film. (B) Live-dead assay of NIH-3T3 cells stained with calcein AM dye and PI. (C) SEM images of PVA@a $a_{m}-\mathrm{ZnO} @ \mathrm{CuO} @ \mathrm{Au}$ film exposed to PRP of the human. (D) SEM images of the RBCs morphology in the presence of PVA@a $a_{m}-\mathrm{ZnO} @ \mathrm{CuO} @ \mathrm{Au}$ film. (E) Hemolytic assay of PVA@a $a_{m}-\mathrm{ZnO} @ \mathrm{CuO} @ \mathrm{Au}$ film by human red blood cells. (F) Optical images of red blood cells treated by PBS (control) and PVA@a $a_{m}-\mathrm{ZnO} @ \mathrm{CuO} @ \mathrm{Au}$ film.

RBCs have been widely used in biosafety evaluations of various biomedical materials, as blood-contact biomaterials will inevitably interact with RBCs [43]. In this work, we studied the effect of PVA@am $\mathrm{ZnO} @ \mathrm{CuO} @ \mathrm{Au}$ film on the morphology and lysis of RBCs to determine the interaction of the PVA@a $a_{m}-\mathrm{ZnO} @ \mathrm{CuO} @ \mathrm{Au}$ film with RBC membrane structure. Fig. 5D shows RBCs in the presence of PVA@a $a_{m}-\mathrm{ZnO} @ \mathrm{CuO} @ \mathrm{Au}$ film. Overall, the PVA@a $a_{m}-\mathrm{ZnO} @ \mathrm{CuO} @ \mathrm{Au}$ film appeared to affect the RBC morphology in a concentration-dependent manner. Specifically, a few RBCs became crenated in PVA@a $a_{m}-\mathrm{ZnO} @ \mathrm{CuO} @ \mathrm{Au} 3 . \quad$ The results showed that the PVA@am-ZnO@CuO@Au film had a slight interaction with the RBC membrane.

Hemolysis testing determines the solubility of the blood cells in contact with foreign materials and has been a powerful in vitro test to evaluate the hemolysis property of 
wound dressing [44]. It is known that for the materials having potential applications as drug or implanted devices, a hemolysis rate of lower than $5 \%$ is required. It is seen from Fig. 5E that PVA@am- $\mathrm{ZnO} @ \mathrm{CuO} @ \mathrm{Au}$ film hemolysis percentages were far below the demanded level of 5\%. As shown in Fig. 5F, the morphology of red blood cells (RBCs) did not undergo obvious changes in the presence of PVA@a $a_{m}-\mathrm{ZnO} @ \mathrm{CuO} @ \mathrm{Au}$ film as compared to the negative and positive controls. These results indicated that the PVA@a $a_{m}-\mathrm{ZnO} @ \mathrm{CuO} @ \mathrm{Au}$ film were safe for blood-contact applications and were suitable for wound healing.

\subsection{In vivo evaluation of wound healing}

To evaluate the wound healing capacity on diabetic wounds during the healing process, PVA@am-ZnO@CuO@Au film was applied to wound sites. The groups treated with PVA@am-ZnO@CuO@Au film with635 nm laser irradiation exhibited enhanced healing after 10 days of implantation, compared to control (pure PVA only) and PVA@am-ZnO@CuO@Au film without red laser irradiation (Fig. 6A). Specifically, the PVA@am-ZnO@CuO@Au film without red laser irradiation showed better healing potential than the controls with wound areas of $77 \pm 3.1 \%$ (PVA@a $\left.a_{m}-\mathrm{ZnO} @ \mathrm{CuO} @ \mathrm{Au}\right)$, $60 \pm 2.6 \%\left(\mathrm{PVA} / a_{m}-\mathrm{ZnO} @ \mathrm{CuO} @ \mathrm{Au}\right.$ 2), and $38 \pm 3.2 \%\left(\mathrm{PVA} @ a_{m}-\mathrm{ZnO} @ \mathrm{CuO} @ \mathrm{Au} 3\right)$ of the initial wound size at day 10 (Fig. 6B). We suspect that the PVA@a $a_{m}-\mathrm{ZnO} @ \mathrm{CuO} @ \mathrm{Au}$ film released $\mathrm{Cu}^{2+} / \mathrm{Zn}^{2+}$ and generated heat $/ \mathrm{ROS}$ to the wound areas to facilitate healing processes. Interestingly, the wounds treated with PVA@a $a_{m}-\mathrm{ZnO} @ \mathrm{CuO} @ \mathrm{Au} 3$ with red laser irradiation showed complete closure at day 10. Thus, combining an appropriate dressing material (PVA@a $a_{m}-\mathrm{ZnO} @ \mathrm{CuO} @ \mathrm{Au}$ film) with $635 \mathrm{~nm}$ laser irradiation could enhance the wound healing process in vivo. 


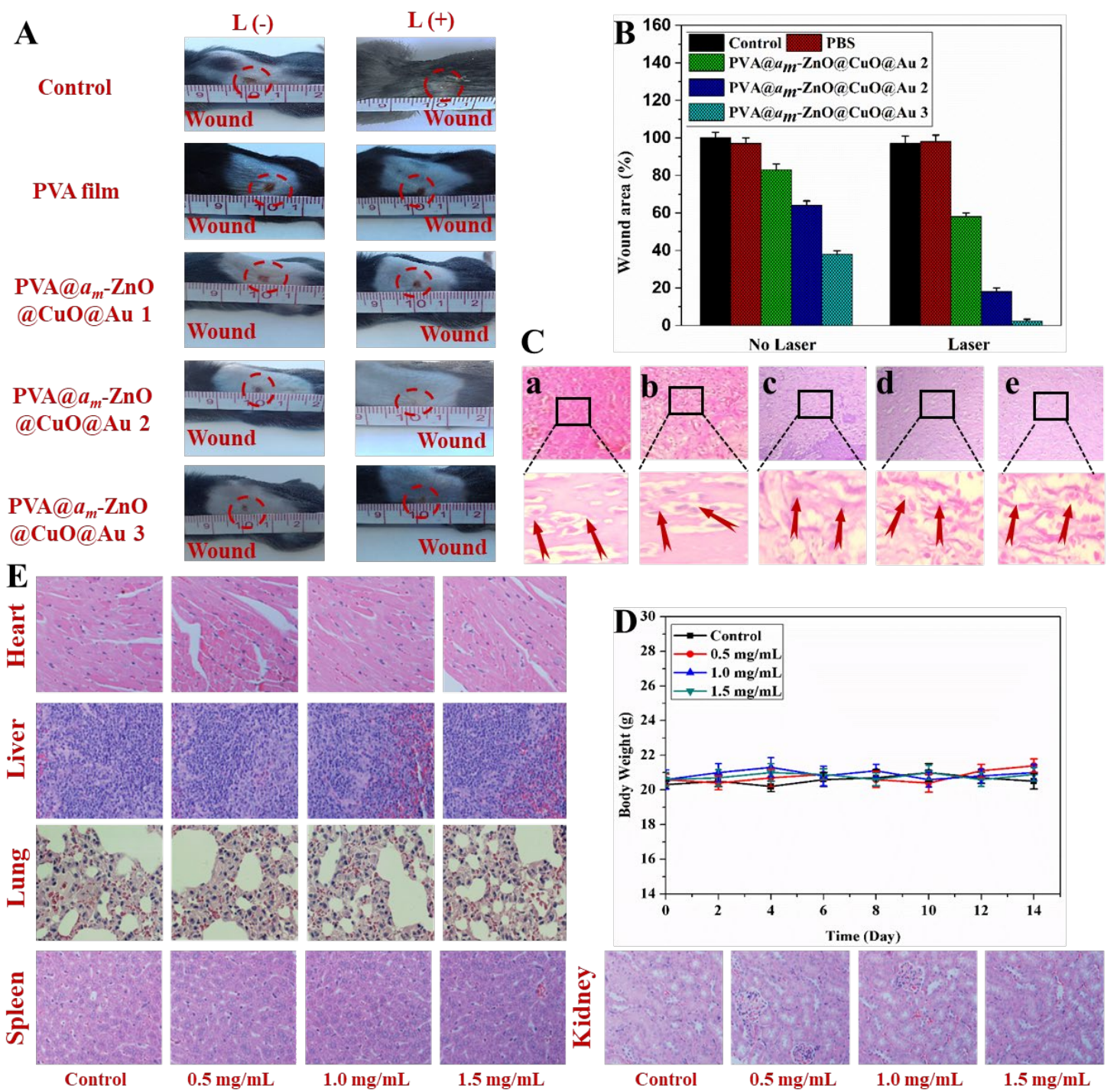

Fig. 6. (A) Photographs of the wound on the mice at 10 days. (B) Corresponding wound area at 10 days. (C) Histological photomicrographs of wound surface at different magnifications (a control; b, pure PVA film+red laser; c-e, $a_{m}-\mathrm{ZnO} @ \mathrm{CuO} @ \mathrm{Au}$ 1-3 film+red laser). (D) Body weight versus the number of days after $a_{m}-\mathrm{ZnO} @ \mathrm{CuO} @ \mathrm{Au}$ NPs treatments. (E) Histologicall photomicrographs of major organs after $a_{m}-\mathrm{ZnO} @ \mathrm{CuO} @ \mathrm{Au}$ NPs treatments.

Histological examination (H\&E) of the entire wound healing process was done over a period of 10 days to reveal the healing activity of PVA@am-ZnO@CuO@Au film with red laser irradiation [45]. As shown in Fig. 6C. the wound biopsies from PVA@am-ZnO@CuO@Au film with red laser irradiation showed complete epidermal cover over the wound. Whereas, the pure PVA showed epidermal covering only at the 
edges of the wound. A decrease in the period of epithelization of the treated wounds compared to pure PVA could be attributed to an increase in the rate of wound healing. However, in the deeper tissues, the pure PVA group showed granulation tissue with dilated blood vessels along with fibroblast proliferation differ from the PVA@am-ZnO@CuO@Au film with red laser irradiation, which showed more prominent fibrosis, collagenization, and small blood vessels. Therefore, it can be concluded that the biopsies at 10th wounding day showed good healing with a complete epidermal cover, and replacement of the granulation tissue with fibrosis and collagenization as part of the healing response in PVA@a $a_{m}-\mathrm{ZnO} @ \mathrm{CuO} @ \mathrm{Au}$ film with red laser irradiation. Here, PVA@a $a_{m}$ ZnO@CuO@Au 3 with red laser irradiation showed a greater degree of fibrosis. Pure PVA showed a more delayed healing response with granulation tissue still persisting.

\subsection{Invivo cytotoxicity evaluation of PVA@ $a_{m}-Z n O @ C u O @ A u N P s$}

The US Centers for Disease Control and Prevention reports that NPs can penetrate the skin and into other organs from the respiratory system [42]. Therefore, the biocompatibility of $a_{m}-\mathrm{ZnO} @ \mathrm{CuO} @ \mathrm{Au}$ NPs needed to be evaluated in vivo. Body weight and behaviors of the treated mice were monitored to evaluate in vivo toxicities of am-ZnO@CuO@Au NPs on a daily basis. Treatment with $a_{m}-\mathrm{ZnO} @ \mathrm{CuO} @ \mathrm{Au}$ NPs did not induce any visible adverse reaction on the behaviors or body weight of mice during the 10 days (Fig. 6D). Finally, the pathological figures of major organs (Heart, liver, spleen, lung, and kidneys) were demonstrated by histology at day 10. As shown in Fig. 6E, no apparent damages were detected among organs, especially in the liver, spleen, and kidneys, during the entire time period.

\section{Conclusion}

In conclusion, a new type of PVA film embedded with functional inorganic 
$a_{m}-\mathrm{ZnO} @ \mathrm{CuO} @ \mathrm{Au}$ NPs was prepared and characterized. It showed significant antibacterial efficacy against S. aureus $(99.80 \%)$ and E. coli $(97.5 \%)$ within 10 min after application, on account of the combined action of PTT, PDT, and $\mathrm{Zn}^{2+}$ and $\mathrm{Cu}^{2+}$ under $635 \mathrm{~nm}$ laser irradiation. The volume variation of this film can be controlled by the red laser to alter the rate of release of $\mathrm{Zn}^{2+}$ and $\mathrm{Cu}^{2+}$ to the physiological environment. In addition, this study demonstrated that the as-fabricated PVA@am-ZnO@CuO@Au film had excellent biocompatibility, high stability at physiological conditions. In vivo wound therapeutic outcome also demonstrated that the film accelerated wound healing compared with the control groups. Therefore, the PVA@a $a_{m}-\mathrm{ZnO} @ \mathrm{CuO} @ \mathrm{Au}$ film is promising for use in clinical treatment of wound infection.

\section{Acknowledgements}

This work was supported by the Jiangsu province science and technology support plan (BE2015367), and the Villum Fonden, Denmark, Project No. 13153. B.S., M.Z., and T.Z. thanks the China Scholarship Council (CSC) for generous support.

\section{Conflict of interests}

The authors declare no conflict of interest.

\section{References}

[1] S. Jiang, B.C. Ma, W. Huang, A. Kaltbeitzel, G. Kizisavas, D. Crespy, K.A.I. Zhang, K. Landfester, Visible light active nanofibrous membrane for antibacterial wound dressing, Nanoscale Horizons. 3 (2018) 439-446. doi:10.1039/c8nh00021b.

[2] S. Hong, T.J. Moritz, C.M. Rath, P. Tamrakar, P. Lee, T. Krucker, L.P. Lee, Assessing Antibiotic Permeability of Gram-Negative Bacteria via Nanofluidics, ACS Nano. 11 (2017) 6959-6967. doi:10.1021/acsnano.7b02267.

[3] J. Zhou, D. Yao, Z. Qian, S. Hou, L. Li, A.T.A. Jenkins, Y. Fan, Bacteria-responsive intelligent wound dressing: Simultaneous In situ detection and inhibition of bacterial infection for accelerated wound healing, Biomaterials. 161 (2018) 11-23. doi:10.1016/j.biomaterials.2018.01.024.

[4] W. Yin, J. Yu, F. Lv, L. Yan, L.R. Zheng, Z. Gu, Y. Zhao, Functionalized Nano-MoS2 with 
Peroxidase Catalytic and Near-Infrared Photothermal Activities for Safe and Synergetic Wound Antibacterial Applications, ACS Nano. 10 (2016) 11000-11011. doi:10.1021/acsnano.6b05810.

[5] A. Tricoli, N. Nasiri, S. De, Wearable and Miniaturized Sensor Technologies for Personalized and Preventive Medicine, Adv. Funct. Mater. 27 (2017) 1-19. doi:10.1002/adfm.201605271.

[6] S. Bakhshandeh, Z. Gorgin Karaji, K. Lietaert, A.C. Fluit, C.H.E. Boel, H.C. Vogely, T. Vermonden, W.E. Hennink, H. Weinans, A.A. Zadpoor, S. Amin Yavari, Simultaneous Delivery of Multiple Antibacterial Agents from Additively Manufactured Porous Biomaterials to Fully Eradicate Planktonic and Adherent Staphylococcus aureus, ACS Appl. Mater. Interfaces. 9 (2017) 25691-25699. doi:10.1021/acsami.7b04950.

[7] I. Matai, A. Sachdev, P. Dubey, S. Uday Kumar, B. Bhushan, P. Gopinath, Antibacterial activity and mechanism of $\mathrm{Ag}-\mathrm{ZnO}$ nanocomposite on $\mathrm{S}$. aureus and GFP-expressing antibiotic resistant $\mathrm{E}$. coli, Colloids Surfaces B Biointerfaces. 115 (2014) 359-367. doi:10.1016/j.colsurfb.2013.12.005.

[8] Y. Wang, X. Ding, Y. Chen, M. Guo, Y. Zhang, X. Guo, H. Gu, Antibiotic-loaded, silver core-embedded mesoporous silica nanovehicles as a synergistic antibacterial agent for the treatment of drug-resistant infections, Biomaterials. 101 (2016) 207-216. doi:10.1016/j.biomaterials.2016.06.004.

[9] Y. Li, X. Liu, L. Tan, Z. Cui, X. Yang, Y. Zheng, K.W.K. Yeung, P.K. Chu, S. Wu, Rapid Sterilization and Accelerated Wound Healing Using Zn 2+ and Graphene Oxide Modified g-C 3 N 4 under Dual Light Irradiation, Adv. Funct. Mater. 28 (2018) 1-12. doi:10.1002/adfm.201800299.

[10] H.C. Yang, R.Z. Waldman, M.B. Wu, J. Hou, L. Chen, S.B. Darling, Z.K. Xu, Dopamine: Just the Right Medicine for Membranes, Adv. Funct. Mater. 28 (2018) 1-14. doi:10.1002/adfm.201705327.

[11] D. Avnir, Recent Progress in the Study of Molecularly Doped Metals, Adv. Mater. 30 (2018) 1-6. doi:10.1002/adma.201706804.

[12] A. Nasajpour, S. Ansari, C. Rinoldi, A.S. Rad, T. Aghaloo, S.R. Shin, Y.K. Mishra, R. Adelung, W. Swieszkowski, N. Annabi, A. Khademhosseini, A. Moshaverinia, A. Tamayol, A Multifunctional Polymeric Periodontal Membrane with Osteogenic and Antibacterial Characteristics, Adv. Funct. Mater. 28 (2018) 1-8. doi:10.1002/adfm.201703437.

[13] Y. Yang, L. Ma, C. Cheng, Y. Deng, J. Huang, X. Fan, C. Nie, W. Zhao, C. Zhao, Nonchemotherapic and Robust Dual-Responsive Nanoagents with On-Demand Bacterial Trapping, Ablation, and Release for Efficient Wound Disinfection, Adv. Funct. Mater. 28 (2018) 1-12. doi:10.1002/adfm.201705708.

[14] S. Allahyari, M. Haghighi, A. Ebadi, Direct synthesis of DME over nanostructured CuO-ZnO-A12O3/HZSM-5 catalyst washcoated on high pressure microreactor: Effect of catalyst loading and process condition on reactor performance, Chem. Eng. J. 262 (2015) 1175-1186. doi:10.1016/j.cej.2014.10.062.

[15] L.A. Kunz-Schughart, A. Dubrovska, C. Peitzsch, A. Ewe, A. Aigner, S. Schellenburg, M.H. Muders, S. Hampel, G. Cirillo, F. Iemma, R. Tietze, C. Alexiou, H. Stephan, K. Zarschler, O. Vittorio, M. Kavallaris, W.J. Parak, L. Mädler, S. Pokhrel, Nanoparticles for radiooncology: Mission, vision, challenges, Biomaterials. $120 \quad$ (2017) 155-184. doi:10.1016/j.biomaterials.2016.12.010.

[16] C. Mao, Y. Xiang, X. Liu, Z. Cui, X. Yang, K.W.K. Yeung, H. Pan, X. Wang, P.K. Chu, S. Wu, 
Photo-Inspired Antibacterial Activity and Wound Healing Acceleration by Hydrogel Embedded with $\mathrm{Ag} / \mathrm{Ag} @ \mathrm{AgCl} / \mathrm{ZnO} \quad$ Nanostructures, ACS Nano. $11 \quad$ (2017) 9010-9021. doi:10.1021/acsnano.7b03513.

[17] C. Jin, X. Liu, L. Tan, Z. Cui, X. Yang, Y. Zheng, K.W.K. Yeung, P.K. Chu, S. Wu, $\mathrm{Ag} / \mathrm{AgBr}$-loaded mesoporous silica for rapid sterilization and promotion of wound healing, Biomater. Sci. 6 (2018) 1735-1744. doi:10.1039/c8bm00353j.

[18] Z. Li, Y.W. Yang, Creation and bioapplications of porous organic polymer materials, J. Mater. Chem. B. 5 (2017) 9278-9290. doi:10.1039/c7tb02647a.

[19] Y. Yang, L. Ma, C. Cheng, Y. Deng, J. Huang, X. Fan, C. Nie, W. Zhao, C. Zhao, Nonchemotherapic and Robust Dual-Responsive Nanoagents with On-Demand Bacterial Trapping, Ablation, and Release for Efficient Wound Disinfection, Adv. Funct. Mater. 28 (2018) 1-12. doi:10.1002/adfm.201705708.

[20] W. Miao, H. Kim, V. Gujrati, J.Y. Kim, H. Jon, Y. Lee, M. Choi, J. Kim, S. Lee, D.Y. Lee, S. Kang, S. Jon, Photo-decomposable organic nanoparticles for combined tumor optical imaging and multiple phototherapies, Theranostics. 6 (2016) 2367-2379. doi:10.7150/thno.15829.

[21] Y. Kang, X. Tang, Z. Cai, X. Zhang, Supra-Amphiphiles for Functional Assemblies, Adv. Funct. Mater. 26 (2016) 8920-8931. doi:10.1002/adfm.201602998.

[22] F. Gao, M. Sun, W. Ma, X. Wu, L. Liu, H. Kuang, C. Xu, A Singlet Oxygen Generating Agent by Chirality-dependent Plasmonic Shell-Satellite Nanoassembly, Adv. Mater. 29 (2017) 1-8. doi:10.1002/adma.201606864.

[23] H.K. Moon, M. Son, J.E. Park, S.M. Yoon, S.H. Lee, H.C. Choi, Significant increase in the water dispersibility of zinc phthalocyanine nanowires and applications in cancer phototherapy, NPG Asia Mater. 4 (2012) e12-8. doi:10.1038/am.2012.22.

[24] M. Wegener, M.J. Hansen, A.J.M. Driessen, W. Szymanski, B.L. Feringa, Photocontrol of Antibacterial Activity: Shifting from UV to Red Light Activation, J. Am. Chem. Soc. 139 (2017) 17979-17986. doi:10.1021/jacs.7b09281.

[25] M.A. Mofazzal Jahromi, P. Sahandi Zangabad, S.M. Moosavi Basri, K. Sahandi Zangabad, A. Ghamarypour, A.R. Aref, M. Karimi, M.R. Hamblin, Nanomedicine and advanced technologies for burns: Preventing infection and facilitating wound healing, Adv. Drug Deliv. Rev. 123 (2018) 33-64. doi:10.1016/j.addr.2017.08.001.

[26] J. Zhou, D. Yao, Z. Qian, S. Hou, L. Li, A.T.A. Jenkins, Y. Fan, Bacteria-responsive intelligent wound dressing: Simultaneous In situ detection and inhibition of bacterial infection for accelerated wound healing, Biomaterials. 161 (2018) 11-23. doi:10.1016/j.biomaterials.2018.01.024.

[27] M. Zhang, F. Wu, W. Wang, J. Shen, N. Zhou, C. Wu, Multifunctional Nanocomposites for Targeted, Photothermal, and Chemotherapy, Chem. Mater. 31 (2019) 1847-1859. doi:10.1021/acs.chemmater.8b00934.

[28] M. Zhang, W. Wang, F. Wu, K. Graveran, J. Zhang, C. Wu, Black Phosphorus Quantum Dots Gated, Carbon-Coated Fe 3 O 4 Nanocapsules (BPQDs@ss-Fe 3 O 4 @) with Low Premature Release Could Enable Imaging-Guided Cancer Combination Therapy, Chem. - A Eur. J. 24 (2018) 12890-12901. doi:10.1002/chem.201801085.

[29] M. Zhang, W. Wang, F. Wu, P. Yuan, C. Chi, N. Zhou, Magnetic and fluorescent carbon 
nanotubes for dual modal imaging and photothermal and chemo-therapy of cancer cells in living mice, Carbon N. Y. 123 (2017) 70-83. doi:10.1016/j.carbon.2017.07.032.

[30] J. Mou, T. Lin, F. Huang, H. Chen, J. Shi, Black titania-based theranostic nanoplatform for single NIR laser induced dual-modal imaging-guided PTT/PDT, Biomaterials. 84 (2016) 13-24. doi:10.1016/j.biomaterials.2016.01.009.

[31] D. Yang, G. Yang, P. Yang, R. Lv, S. Gai, C. Li, F. He, J. Lin, Assembly of Au Plasmonic Photothermal Agent and Iron Oxide Nanoparticles on Ultrathin Black Phosphorus for Targeted Photothermal and Photodynamic Cancer Therapy, Adv. Funct. Mater. 27 (2017). doi:10.1002/adfm.201700371.

[32] S. Son, N. Kim, D.G. You, H.Y. Yoon, J.Y. Yhee, K. Kim, I.C. Kwon, S.H. Kim, Antitumor therapeutic application of self-assembled RNAi-AuNP nanoconstructs: Combination of VEGF-RNAi and photothermal ablation, Theranostics. 7 (2017) 9-22. doi:10.7150/thno.16042.

[33] K. Wang, R. Jiang, T. Peng, X. Chen, W. Dai, X. Fu, Modeling the effect of Cu doped TiO2 with carbon dots on $\mathrm{CO} 2$ methanation by $\mathrm{H} 2 \mathrm{O}$ in a photo-thermal system, Appl. Catal. B Environ. 256 (2019) 117780. doi:10.1016/j.apcatb.2019.117780.

[34] K.C. Ok, J.H. Lim, H.J. Jeong, H.M. Lee, Y.S. Rim, J.S. Park, Photothermally Activated Nanocrystalline Oxynitride with Superior Performance in Flexible Field-Effect Transistors, ACS Appl. Mater. Interfaces. 10 (2018) 2709-2715. doi:10.1021/acsami.7b16046.

[35] Q. Yang, Z. Lu, X. Sun, J. Liu, Ultrathin Co 3 O 4 nanosheet arrays with high supercapacitive performance, Sci. Rep. 3 (2013) 1-7. doi:10.1038/srep03537.

[36] R. Yang, R. Li, Y. Cao, Y. Wei, Y. Miao, W.L. Tan, X. Jiao, H. Chen, L. Zhang, Q. Chen, H. Zhang, W. Zou, Y. Wang, M. Yang, C. Yi, N. Wang, F. Gao, C.R. McNeill, T. Qin, J. Wang, W. Huang, Oriented Quasi-2D Perovskites for High Performance Optoelectronic Devices, Adv. Mater. 30 (2018) 1-8. doi:10.1002/adma.201804771.

[37] T. Liu, X. Xue, L. Huo, X. Sun, Q. An, F. Zhang, T.P. Russell, F. Liu, Y. Sun, Highly Efficient Parallel-Like Ternary Organic Solar Cells, Chem. Mater. 29 (2017) 2914-2920. doi:10.1021/acs.chemmater.6b05194.

[38] K. Shivaji, S. Mani, P. Ponmurugan, C.S. De Castro, M. Lloyd Davies, M.G. Balasubramanian, S. Pitchaimuthu, Green-Synthesis-Derived CdS Quantum Dots Using Tea Leaf Extract: Antimicrobial, Bioimaging, and Therapeutic Applications in Lung Cancer Cells, ACS Appl. Nano Mater. 1 (2018) 1683-1693. doi:10.1021/acsanm.8b00147.

[39] S.G. Jin, A.M. Yousaf, K.S. Kim, D.W. Kim, D.S. Kim, J.K. Kim, C.S. Yong, Y.S. Youn, J.O. Kim, H.G. Choi, Influence of hydrophilic polymers on functional properties and wound healing efficacy of hydrocolloid based wound dressings, Int. J. Pharm. 501 (2016) 160-166. doi:10.1016/j.ijpharm.2016.01.044.

[40] J. Qu, X. Zhao, Y. Liang, T. Zhang, P.X. Ma, B. Guo, Antibacterial adhesive injectable hydrogels with rapid self-healing, extensibility and compressibility as wound dressing for joints skin wound healing, Biomaterials. 183 (2018) 185-199. doi:10.1016/j.biomaterials.2018.08.044.

[41] K. Kaviyarasu, N. Geetha, K. Kanimozhi, C. Maria Magdalane, S. Sivaranjani, A. Ayeshamariam, J. Kennedy, M. Maaza, In vitro cytotoxicity effect and antibacterial performance of human lung epithelial cells A549 activity of Zinc oxide doped TiO2 nanocrystals: Investigation of bio-medical 
application by chemical method, Mater. Sci. Eng. C. 74 (2017) 325-333. doi:10.1016/j.msec.2016.12.024.

[42] C. Nie, Y. Yang, C. Cheng, L. Ma, J. Deng, L. Wang, C. Zhao, Bioinspired and biocompatible carbon nanotube-Ag nanohybrid coatings for robust antibacterial applications, Acta Biomater. 51 (2017) 479-494. doi:10.1016/j.actbio.2017.01.027.

[43] C. Ergene, E.F. Palermo, Self-immolative polymers with potent and selective antibacterial activity by hydrophilic side chain grafting, J. Mater. Chem. B. 6 (2018) 7217-7229. doi:10.1039/c8tb01632a.

[44] S. Huo, Y. Jiang, Z. Jiang, R.F. Landis, X.J. Liang, V.M. Rotello, Stable and oxidant responsive zwitterionic nanoclusters, Nanoscale. 10 (2018) 7382-7386. doi:10.1039/c7nr08951a.

[45] S. Anjum, A. Arora, M.S. Alam, B. Gupta, Development of antimicrobial and scar preventive chitosan hydrogel wound dressings, Int. J. Pharm. 508 (2016) 92-101. doi:10.1016/j.ijpharm.2016.05.013.

[46] L. Yildirimer, N.T.K. Thanh, M. Loizidou, A.M. Seifalian, Toxicological considerations of clinically applicable nanoparticles, Nano Today. $6 \quad$ (2011) 585-607. doi:10.1016/j.nantod.2011.10.001. 